In : Royse, K R, Reeves, H J, and Gibson, A R. 2008. The modelling and visualisation of digital geoscientific data as an aid to land-use planning in the urban environment, an example from the Thames Gateway. Communicating Environmental Geoscience. Liverman, D G E, Pereira, C, and Marker, B (editors). Geological Society, London, Special Publication, 305.

\title{
The modelling and visualisation of digital geoscientific data as an aid to land-use planning in the urban environment; an example from the Thames Gateway
}

\author{
K.R. Royse, H.J. Reeves and A.G. Gibson
}

British Geological Survey, Keyworth, Nottingham, NG12 5GG

Corresponding author: Kate Royse

Number of Words of: Text $=6,036$, References $=1,690$, Tables $=765$, Figures $=255$

Abbreviated Title: Modelling and visualisation of geoscience data

\begin{abstract}
The Thames Gateway development zone is the biggest urban development project in the UK for over 50 years. For that reason, developers and planners need to understand the implications of such large-scale urbanisation on the environment. Requirements for sustainable growth within the Thames Gateway region means that, increasingly, developers are being required to demonstrate that proposals are based on sound scientific information. This has resulted in a growing demand for geo-environmental information to be provided in more accessible, relevant and understandable forms.
\end{abstract}

Advances in the use of Geographical Information Systems (GIS) and 3D modelling software have meant that there is now far greater opportunity to develop geo-environmental information products for urban development. As a result of this, new and innovative ways of visualising and communicating geoscience information have been developed. Using this new technology it is possible to predict not only the types of rocks beneath a site, but also the engineering properties (such as rock strength, shrink-swell characteristics or compressibility), hydrogeological properties (such as permeability, porosity and thickness of the unsaturated zone) and geohazard potential. Geoscientific information can then be imported into standard GIS packages and queried along with other complementary ground investigation data, resulting in the creation of a powerful tool to assist in strategic planning and sustainable development.

\section{Introduction}

The importance of good quality geo-environmental information is becoming increasingly important as new guidance and legislative changes (such as the Planning Policy statements 
[PPS] 9 (DCLG, 2006), 23(ODPM, 2004) and 25 (CLG, 2006), the water framework directive and part IIA of the Environment Protection Act, 1990) have forced developers, planning authorities and regulators to consider the implications and impact of large-scale development initiatives on the environment. To comply with the principles of sustainable development, developers increasingly are required to demonstrate that proposals are based on the best possible scientific information and analysis of risk. Nowhere are these issues more relevant than in the context of the urban environment.

The case for using geo-environmental information to underpin preliminary site appraisal and for developing regional strategies has been made elsewhere and is discussed in depth by Culshaw et al.(1994), Ellison et al.(1998), McKirdy et al.(1998), Thompson et al.(1998), Bobrowsky (2002), Culshaw \& Ellison (2002), and Ellison et al.(2002). In the UK, studies commissioned by the Department of the Environment in the 1980s and 1990s (Smith \& Ellison 1999) promoted the use of applied geological maps to identify the principal geological factors that should be taken into account for development planning. Since this work was completed, advances in the use of Geographical Information Systems (GIS) and 3D modelling software have meant that there is now a greater opportunity to develop geo-environmental information systems for urban development, which can take greater account of the third dimension. As a result, new and innovative ways of communicating and visualising geoscientific information have been developed.

The research on which this paper is based focuses on London and the Thames Gateway development zone, but builds on earlier work in Manchester and Salford (Culshaw 2005, Lelliott et al. 2006). London is one of the most densely populated cities in Europe. The Mayor of London's Plan (The Mayor of London 2004) predicts that the total population of London will rise by 900,000 by the year 2016. For London to cope with such a huge increase in population, it must grow and develop fast. The only way this can be achieved is by development taking place outside London's current boundaries. As a result, a 40-mile stretch of land running eastwards from the east end of London, along both north and south banks of the River Thames towards Southend-on-Sea, forms the area known as the Thames Gateway Development Zone (TGDZ; Figure 1). It is currently the focus of the biggest building programme to be undertaken in the UK for over 50 years.

A large proportion of the planned development projects in the Thames Gateway will necessitate construction on ground that contains highly compressible soils, shrinking and swelling clays, high groundwater levels, potentially contaminated brownfield sites and ground which is affected by other geohazards. Failure to fully appreciate the ground conditions at the planning stage of any development is likely to prove costly and may lead to project over-run (Marker 1998). A report by the Institution of Civil Engineers in 1993 found that of the 5000 industrial building projects that they surveyed, nearly all those that overran were due to problems created by unforeseen ground conditions (Site investigation Steering Group 1993). The Thames Gateway planning framework document (RPG 9A, Anon 1995) recognises numerous issues related to geology. These include such issues as dealing with existing and potential land contamination, preservation of the natural environment (including sites of geological interest) and flood risk. Yet, unlike the Environment Agency and the Countryside Agency, the British Geological Survey has not been a statutory consultee in the planning process for the TGDZ.

If sound decisions are to be made then, clearly, those organisations involved in planning and development need access to all relevant information. This paper explores new ways that 
geoscientists can present and communicate their information, so that regional development strategies include relevant geoscientific information and that land-use planners can obtain a better understanding of the relevance of geoscientific data in planning and development. 


\section{Geological setting}

The TGDZ is contained within the London Basin (Fig. 1). The London Basin is a broad, gentle synclinal fold whose axis can be traced from Marlborough through to Westminster. The London Basin formed in Oligocene to mid- Miocene times during the main Alpine compressional event. Formations in this region range from Cretaceous (144 to $65 \mathrm{Ma}$ ) to Quaternary (2 Ma to present day) in age.

The Cretaceous Chalk is typically a fine grained white limestone (Bristow et al.(1997) provides a detailed description of the Chalk lithostratigraphy). It has a total thickness of between 175 and $200 \mathrm{~m}$ and generally thins from the west to the east. Overlying the Chalk is the oldest Palaeogene deposit, the Thanet Sand Formation. This formation consists of a coarsening upwards sequence of fine grained, grey sand. The formation reaches a maximum thickness of around $30 \mathrm{~m}$ in the area. A basal conglomerate (the Bullhead Beds) defines the base of the Thanet Sand, which consists of rounded black flint pebbles. Above the Thanet Sand Formation lies the Lambeth Group. This Group consists of three formations: the Upnor, the Woolwich and the Reading Formations. The Lambeth Group is between 20 and $30 \mathrm{~m}$ thick in the area and lithologically the group is highly variable, consisting of variable proportions of sands, silts, clays and gravels.

Overlying this are the Eocene sediments of the Thames Group which consist of the Harwich and London Clay Formations. The Harwich Formation (formally known as the Blackheath or Oldhaven Beds) consists predominantly of sand and pebble beds up to $4 \mathrm{~m}$ thick. Above this is approximately 90 to $130 \mathrm{~m}$ of London Clay. The London Clay Formation consists of grey to blue grey, bioturbated, silty clay. Quaternary deposits are encountered right across the TGDZ. These include evidence of an ancient river system and the development of the present day River Thames valley. Deposits include alluvium, peat, brickearth and river terrace deposits (for example, the Kempton Park, Taplow and Shepperton Gravels).

\section{Requirements for digital geoscientific data}

The essential function of land-use planning can be summarised as 'the scientific, aesthetic, and orderly disposition of land, resources, facilities and services with a view to securing the physical, economic and social efficiency, health and well-being of urban and rural communities' (Canadian Institute of Planners 2000). This requires planners to consider the social, economic and political needs of their area as well as the needs of the environment. Geological and geotechnical issues tend to appear well down the list of priorities (Paul et al. 2002). All too often it is only after problems have occurred that attention is turned towards geological and geotechnical issues.

New guidance and legislative changes such as PPS 9, 23 and 25 have forced planners and developers to consider the implications of large-scale development initiatives on the environment. Policy documents such as: Anon (1995) The Office of the Deputy Prime Minister (2004) and Thompson et al.(1998) have resulted in an increased awareness of the importance of geoscientific data in land-use planning and a requirement to base planning decisions on the best available environmental information. This has resulted in geoscientists making increasing efforts to provide planners with relevant geological information (Smith \& 
Ellison 1999). However, the final project output has often resulted in the work being presented in a form which does not meet the needs of planners, many of whom do not have a geoscientific background (Marker 1998). Turner (2003) suggested that most geoscientific information systems fail, not because they were inadequate scientifically or technologically, but because the system did not meet the needs of the user community it was designed to serve.

Geoscientists have principally two problems to overcome. Firstly, the traditional method of visualising geoscientific information is to produce a geological map. Although an excellent way of recording several sets of 2D information on a flat surface, it requires a significant amount of expert knowledge to interpret its meaning. For the non-geoscientist the geological map presents itself as a confusing array of colours and lines, which have little relevance to the users' everyday working lives. Secondly, with changes in planning policy, there has been a significant change in the type of data-users requiring geoscience information. Data-users can be divided into two camps, 'thick' and 'thin' (Turner 2006). Traditionally, geoscientific information has been provided to 'thick' clients. 'Thick' clients are those who are happy to interpret and manipulate raw data; typically they are keen to have large quantities of uninterpreted data e.g. academics. 'Thin' clients, in contrast, desire simple, concise data which answers precise questions (Turner 2006). 'Thin' clients make up the majority of planners and developers. This view is supported by Culshaw (2003), who suggested that academic users were no longer the most important users of geoscientific information. Therefore, if geoscience data is going to be used widely within the land-use planning sector, geoscientists need to rethink, radically, the way geoscientific data is presented and visualised.

Turner (2003) indicated that generic products are often insufficient to meet the needs of a specific user group such as planners, suggesting instead that geoscientists should concentrate on producing customised products. Therefore, before the geoscientist can produce such outputs three questions must be considered:

1. What geoscientific information do planners and developers need?

2. What type of geoscience data is required to meet these needs?

3. Why is geoscientific data not always fully utilised?

Urban areas require geological resources for construction and maintenance (Marker, 1998). They also require geological data to ensure that sterilisation of resources or contaminative activities close to vulnerable aquifers do not occur. With these views firmly in mind, several authors such as: Brook \& Marker (1987), Marker (1998), Bell \& Culshaw (1998), Smith \& Ellison (1999), Howland (2000), and Paul et al. (2002) have suggested what types of geoscientific data planners and developers require:

- $\quad$ Lithostratigraphical geology (at site, area and regional scale)

- Geomorphology

- The nature and use of ground materials

- $\quad$ The availability and quality of water

- The susceptibility of aquifers to pollution

- Natural and anthropogenic geohazards

- $\quad$ The engineering behaviour of the ground

- Land that may be contaminated

- Identification of development potential (constraints on and resources for development) 
To find out why geoscientific information is not being fully used and applied, the views of around 20 stakeholders within the Thames Gateway region were sought from a variety of professions, including local and regional government, utility industries, government agencies, geotechnical and engineering companies and local development agencies and corporations. This information was combined with information from previous studies, such as: Nickless (1982), De Mulder (1988), Thompson et al. (1998), Ellison et al. (1998), Marker (1998) and Culshaw \& Ellison (2002). All this information has been incorporated into table 1. From these discussions it can be concluded that three distinct concerns affect the greater use of geoscientific information. These relate to its relevance, interpretation and visualisation (Royse et al. 2005). Using the Thames Gateway area as a case study this paper will show how geoscientific information can be interpreted and visualised appropriately, and hence made more relevant to planners and developers.

\section{Responding to Users Needs}

Two key advances have enabled geoscientists to change the way they present data to planners and developers. Firstly the availability of geoscientific data in (computer-readable) digital form (Bowie 2005, Jackson 2004) and secondly, advances in GIS and 3D modelling software which has meant that there is now a greater opportunity to develop geo-environmental information systems for the urban environment, which significantly can take account of the 3rd dimension.

In the past, one of the main reasons why many professionals have not used 3D digital models routinely is because many modelling packages are too complex to use (Hack et al. 2006). A key development in changing that perception has been the advances in 3D modelling capabilities and software development, which allows geologists to construct 3D models much more easily (Culshaw 2005, Hinze et al. 1999, Sobisch 2000). Due to developments in 3D viewing software (Sobisch 2000), 3D models can now be viewed and manipulated on a standard desktop computer and, more importantly, updated quickly and easily when new data becomes available. Models can be attributed with physical, chemical or hydrogeological parameters. Once the attributed 3D model is completed, a large number of customised geoscientific outputs can be generated, with little computation (Fig 2). These are major steps forward from previous 3D urban modelling systems, for example, Strange et al. (1998), which required a significant amount of specialist computer knowledge and access to large computing capabilities. Data outputs also tended to be static, as updating was difficult and time consuming.

In the following sections, this paper explores how the main needs of planners and developers (Table 1) can be fulfilled by the use and manipulation of digital geoscientific data and 3D geological models:

\section{Making the best of natural resources}

To manage natural resources effectively (e.g. biodiversity, soil, land and water) planners need to integrate a scientific understanding of environmental processes with an appreciation of socio-economics. Geoscience information can help in a variety of ways from the location and distribution of mineral-rich layers to improving groundwater management and protection plans.

\section{Geodiversity maps}


An appreciation of geodiversity is important to gain a full understanding of many aspects of biodiversity. Geodiversity offers very substantial opportunities to enhance the conservation, management and educational use of land within a region; it is, therefore, an essential part of green network planning (Office of the Deputy Prime Minister \& Department of Environment Food and Rural Affairs 2004). However, until the changes in PPS9 in August 2005, geodiversity has received little serious consideration.

Geodiversity interests need to be integrated into management and conservation strategies for related or parallel interests, including wildlife and archaeological features. The key to doing this is providing planners with spatially registered digital geoscientific data, which can then be queried with other environmental information within a standard GIS system. Geodiversity issues contribute significantly to informing a wide range of planning and environmental policies.

Geodiversity audits have been carried out by the British Geological Survey, most recently for Northumberland (Lawrence et al. 2007). Although none have been compiled yet for the Thames Gateway, the same principles would apply. In each case a spatial database is set up, whereby geological sites and landscape features are explained and evaluated, thereby setting them in a local, regional, national and, where appropriate, international context for local authorities. These data can then be queried, along with other spatially referenced datasets. The resulting GIS system can be used to assess the number of environmental assets present within a region (Steadman et al. 2004).

\section{Location and distribution of mineral rich layers}

Probably the best way to provide an indication of the geometry, distribution and spatial relationship of gravel deposits within the Thames Gateway region is to produce a 3D geological model. The Thames Gateway model was built using over 4000 borehole logs and creating over 200 north-south and east-west trending cross-sections. The model was then constructed using a generalised vertical section (GVS) of the lithostratigraphy, which, when combined with the generated cross-sections, created a fence diagram of the geology (Fig 3). The geological fence diagram of the superficial and bedrock geology were 'hung' from, and constrained by, recent 1:10 000-scale digital geological mapping and a digital terrain model (DTM) of the area.

Fig. 4 displays part of the 3D geological model for the TGDZ. The model provides the user with a view of the geometry and spatial distribution of each of the geological formations within the Thames Gateway area. The user is also able to visualise the variations in thickness. For example, in Fig. 5 the thickness of the alluvial deposits changes from 1-5 $\mathrm{m}$ in the west to $20 \mathrm{~m}$ in the east. Using a traditional 2D paper map with borehole data, interpreting the same information would require a significant amount of time and effort by a geologist. The advantage of the digital 3D model is that this information can be more readily communicated and made available.

\section{Identification of strata rich in archaeological deposits}

The 3D model can also be used to provide information on the likelihood of archaeological remains being present within a particular site; in London and the Thames Gateway area archaeological remains can be linked to the palaeo-environment and hence the geology (Bates 1998, Bates \& Bates 2000). As a result, the 3D geological model can be used by archaeological units within local governmental planning departments to provide advice on whether developments are taking place within potentially archaeologically-rich strata and 
hence whether particular planning conditions should be applied and specialist investigations required.

\section{Groundwater management}

The Thames Gateway 3D geological model can be used as a framework to help develop a conceptual model of the hydrogeological system, essential in understanding groundwater flow and pollution transport. There are a number of ways this can be achieved, such as: using the model to understand the geometry and distribution of hydrogeologically important units; adding hydrogeological parameters to the geological model (such as permeability or porosity); displaying water surfaces on to the geological model and the creation of geology maps from the model at a given potentiometric surface. Attributing the 3D geological model enables the user to view and analyse the vertical and lateral variation in hydrogeological properties, rather than the variation in lithostratigraphy. For example, if high permeability units were required say for the assessment of aquifer storage and recovery potential, then these units, their depth, thickness, and lateral extent can be quickly identified (Fig. 6). The 3D models can also be linked to 4D process models (such as MODFLOW and ZOOMQ3D, Jackson, 2001) that show movement of groundwater through the system.

The 3D model can also be used to define areas or domains of recharge and discharge, that is, to identify sequences of lithologies that are likely to be characterised by similar hydrogeological properties. The models can then be used to assist with water resource management strategies at a regional and site specific level (for example, Lelliott et al. 2006). The use of this domain style of mapping in the context of aquifer recharge or discharge is not new (Dochartaigh et al. 2005, McMillan et al. 2000). However, exporting the 3D geological model as gridded surfaces into a GIS system means that the model can be spatially queried. By identifying and describing each of the domains and by formulating a set of spatial rules, to describe each unit, a thematic recharge or discharge map in 2D is produced which displays complex packages of sediments, defined from the 3D model (Lelliott et al. 2006). The resulting thematic map (Fig. 7) simplifies what is often a complex and diverse collection of anthropogenic, superficial and bedrock deposits, by placing the information into a form which can be more easily understood.

\section{Understanding the site}

According to the UKs Government's sustainable communities policy (Office of the Deputy Prime Minister 2003) " [Land-use] Planning shapes the places where people live and work and the country we live in. Good planning ensures that we get the right development, in the right place and at the right time. It makes a positive difference to people's lives and helps to deliver homes, jobs, and better opportunities for all, whilst protecting and enhancing the natural and historic environment'. Consequently Sustainable development is at the very core of planning policy in the UK today. The World Commission on Environment and Development (Bruntland 1987) defined sustainable development as: "development that meets the needs of the present without compromising the ability of future generations to meet their own needs." If such policies are to be acted upon, it is essential that land-use planners understand the significance of geoscience information in providing a better context for design of site investigations (Marker 1998). The examples below indicate how geoscientific data and 3D models, especially when attributed with property data, can provide land-use planners with a thorough understanding of the shallow sub-surface. 
The 3D model can be used to assess the risk of a new development contaminating the local groundwater supplies. Contamination studies concentrate on the linkages between source and receptor (the 'pathway'). The 3D model can be used to assess these potential links. An example of this is the Lower Lea Valley. Here, thick sequences of superficial deposits comprising River Terrace Gravels and Alluvium are underlain by Palaeogene deposits of the London Clay Formation with the Lambeth Group below. A detailed description is given by Ellison et al. (2004). Where the London Clay is absent and the superficial deposits rest on the Lambeth Group (which consists of interbedded layers of clay and sand) for example, near Stratford Marsh, there are significant implications to the development of pathways from the surface to the Chalk aquifer. As the Lambeth Group is extremely variable, it is likely that at some locations the clay layers may be thin or absent, consequently, the Chalk aquifer will be partially or wholly unconfined. A similar situation occurs in the Kempton Park Gravels where irregularities in the rockhead surface (scour hollows) are known to exist (Berry 1979). The scour hollows can be as much as $15 \mathrm{~m}$ in depth; in these instances, the scouring will have removed the clay layers from within the Lambeth Group and, as a result, a direct pathway is established between surface water and the Chalk aquifer. By using the 3D geological model it is possible to locate sites where these situations are likely to occur and hence, at an early stage, identify these potentially problematical ground conditions.

\section{Foundation conditions and geotechnical classification of ground at depth}

For engineering applications the modelling provides a three-dimensional framework in which spatial presentation and interpretation of geotechnical data can be undertaken. From this spatial information, an engineering geological classification can be formulated and hence the engineering geological ground conditions can then be visualised in 3D. Engineers and geologists can use this visualisation to assist in the recognition and identification of problematic ground conditions, to help design more appropriate ground investigations and contribute to the most efficient foundation design.

Synthetic geological cross-sections and borehole logs can be generated along a specified route enabling an interpretation of the subsurface geology beneath the route to be formulated. For example, a synthetic section can be generated along a given linear route such as railway track. Once a geological appraisal of a section of track has been prepared (Fig. 8), an engineering geological interpretation can be undertaken (Fig. 8). This involves the use of different types of geotechnical test data (for example, standard penetration test, moisture content, particle size distribution) to aid in the interpretation and assessment of the ground conditions. This assessment is undertaken in accordance with BS5930 (British Standards Institution 1999) to determine the grain size (clay, silt, sand, gravel etc.) and strength/density, thus enabling the ground conditions to be classified into a number of engineering geological units (Table 2). In the TGDZ, the geological model was characterised using particle size distribution and standard penetration test data, held in the National Geotechnical Database (maintained by the British Geological Survey). This enabled ten engineering geological units to be identified (Table 2). This classification was then applied to the synthetic geological cross-section and an engineering geological section was produced (Fig. 8). Visual inspection of Fig. 8 allows zones of potentially difficult ground conditions to be identified.

It is now not sufficient to identify, say fine-grained soils as locations for potentially problematic ground conditions as was done in the past using 2D geological maps. More information is required about the geological structure, lithological variability, mineralogy, moisture content and geotechnical properties of the rocks and soils, much of which can be 
supplied from 3D geospatial databases. These databases can be interrogated at key depths to show the wide variability of geological materials and conditions beneath the ground surface. Detailed geological sections along linear routes, such as the example shown from the c2c train operating company's railway route from Purfleet to east Tilbury, can be modelled and the locations of potential problematic rocks and soils, such as alluvium and peats, can be identified (Fig. 8). Spatial attribution of geotechnical data and simple methods to recast sections in engineering geological terms are easily realised using these new techniques. Such attributed sections are an additional tool in strategic infrastructure (for example, rail and road) maintenance and network expansion plans.

\section{Site investigation planning tools}

Once a 3D geological framework has been created geotechnical, hydrogeological data and maps, utility maps, mine plans etc can be added into a GIS system where site investigation planning tools can be created. Using these tools, it is possible for ground investigations to be targeted to areas where the GIS system shows data to be incomplete or where the ground conditions are problematic. These GIS systems can be viewed from a desktop PC, making the modelled data far easier to use on a day-to-day basis. It is also possible for data to be updatable so that site investigation data can be used to advise developers during the construction process (Kaalberg et al. 2003).

\section{Assessment of urban drainage}

Sustainable Urban Drainage Systems (SUDS) are an alternative approach to conventional drainage systems, which replicate, as far as possible, natural drainage systems in order to manage rainwater runoff effectively. The successful implementation of SUDS, (that include swales, balancing ponds and porous pavements) can save money, reduce pollution and alleviate flood risk (CIRIA 2001). BGS has developed a method within the Manchester Urban Project (Lelliott et al. 2006) which has since been applied to the TGDZ, and allows the assessment of SUDS to be carried out quickly and simply at the site planning stage of the project. The assessment is made by reference to the 3D lithological model (type of rock and soil), the topographic slope angle, the permeability of the near-surface deposits and the thickness of the unsaturated zone. The data are then combined into a simple tri-category map; areas more suited to infiltration techniques (e.g. porous pavements) can then be easily identified.

This system is now being developed to incorporate other issues such as potential contamination, present day land-use, aquifer vulnerability, to provide a more realistic picture of the environmental considerations necessary for the implementation of a successful SUDS scheme.

\section{Geohazard maps}

Despite the TGDZ's low relief, lack of soluble or collapsible deposits and distance from any large seismic sources, it is actually one of the areas of Britain most affected by geohazards. As described, most of the TGDZ is underlain by the London Clay formation. Problems associated with this material, at surface and at depth are well known to the construction industry (for instance, Burnett \& Fookes 1974, Chandler \& Apted 1988, Dimmock \& Mair 2007, Hight \& Jardine 1993). This overconsolidated, highly plastic clay is particularly susceptible to shrink-swell activity, and, when on a slope, is prone to mass-movement and landslides (Hutchinson 1965, Forster 1999). 
Demonstrating, describing and quantifying the extent and impacts of shrink-swell activity is more difficult; building distress resulting from ground shrinkage is often categorised as 'subsidence' damage. Insurance claims resulting from such damage are higher in areas underlain by the London Clay, though for commercial reasons, detailed data are usually unavailable. Doornkamp (1995) offered an insight into how closely insurance premiums reflect geological reality.

In order to communicate the presence and severity of these hazards to a wide range of audiences, BGS has developed a National Geohazard Assessment - GeoSure. This GIS based model provides an interpretation of the geological map that includes consideration of geotechnical data, geohazard data, published literature and expert judgement. Potential users of the data indicated that they wanted little or no geological information to be visible at point of use (though this is accessible to expert users). The dataset had to be compatible with a wide variety of GIS systems, paper based systems and computer-driven decision support systems, usually operated automatically or by staff with little or no geological knowledge. In its simplest form, GeoSure provides a hazard assessment of the ground at any location on the mainland, describing hazard potential between A (very low) and E (very high).

Although superficially simple, the national model is based upon over 700,000 GIS components and 10,000 different rock types, each of which were attributed. The system initially took over five years to assemble, and is updated every year, as our understanding of earth systems improves and geological maps are updated.

For the shrink-swell model of Great Britain, use is made of the National Geotechnical Information Database, which contains information derived from over 1000000 downhole tests. Using a GIS system, the borehole data (alongside other information) is used to attribute each rock type in the country with a shrink-swell potential rating, with ratings correlated with volume change potential. The data is then modified by a further factor that takes into account the thickness of any superficial materials near to surface. Figure 9 shows the results of this modelling in the Hadleigh area, where a complex (from the perspective of the general public) geological sequence involving the London Clay Formation, Claygate Gate Member and the Bagshot Formation are overlain by Head and a sequence of Quaternary Gravels. The shrinkswell model of the area reflects how this succession influences the volume change capacity of the ground at near surface.

Similarly, for the Hadleigh area, Figure 10, shows the potential for slope instability. The diagram clearly shows slope instability to the south of Hadleigh, where slopes in the London Clay have been steepened by long-term erosion of the coast.

\section{Setting policy}

Within the UK, the overarching framework for land-use planning is to secure the most efficient and effective use of land in the public interest. With an increased emphasis on sustainable development, there has been pressure on local authorities to take a longer-term view of the likely impact which decisions involving the environment can have. To make the best decisions, planners are required to link science to policy (Culshaw et al. 2006). The UK government has promoted a range of e-government initiatives with the intention to increase the use of information technology and web-based services in planning (see: www.planningportal.gov.uk ). 
In the above sections, the use of geoscientific data to inform decisions on groundwater management, foundation conditions, ground investigations and contamination issues has been discussed. Many of these can be used at both the site specific and regional scale, resulting in the production of regional attributed geological models and regional groundwater management plans. Another area of research has been the development of decision support tools such as the Environmental Information System for Planners (EISP), (Culshaw et al. 2006). The EISP is a web-based system designed to support decision-making within the UK by making environmental issues more widely accessible. The system is configured to support three planning functions: pre-application advice, development control and strategic planning which it does by linking together geoscientific information with best practice and planning guidelines.

\section{Future Developments}

With changes in legislation increasing the importance of geo-environmental information, land-use planners are now required to consider the implications and impact that large-scale development will have on the environment. Land-use planners, although willing to use geoscientific data, have placed demands on geoscientists to make their data more accessible, reliable and understandable. The traditional geological map is no longer an appropriate medium by which to present geo-environmental information. Geoscientists have learnt that it is essential to understand their clients, individual needs in order to provide appropriate customised data outputs. It is only in this way that geoscientists within the urban environment can ensure that geoscientific data will be used within the planning process.

Advances in 3D modelling software and GIS techniques have resulted in a revolution in the way that geoscientific data can be displayed and interpreted. This has allowed urban geoscientists not just to provide raw geological data but to produce integrated geoscientific information ideal for use within land-use planning. This information is provided within a 3D geological model, which is attributed with property data or a GIS system. The 3D attributed geological model can be used to predict not only the rock and soil type but also the variation in properties within any particular unit or formation. As a consequence, the new modelling systems produce detailed and regional 3D models (Howland 2000, Strange et al. 1998), as well as models attributed with physical, chemical or hydrogeological property parameters, potentially at near site scale. As a result, these models can be used to provide solutions to many geo-environmental issues raised during the planning process. By using the 3D geological model in this manner, it has been demonstrated that geoscientists are now moving from conceptual ground models towards more realistic ground models based on actual ground investigation data (Culshaw 2005).

There are three main issues which will need to be resolved in the future. Firstly, all users of digital geoscience data must understand the limitations of the data on which they base their assessments. This is becoming more critical as improvements in 3D modelling techniques are allowing geoscientists to introduce a far greater level of realism to their models. It is essential, therefore, that planners can differentiate between observed and conjectural information. This is often referred to as the inherent uncertainty of a digital 3D model and the geoscientific datasets on which it is based. There are still difficulties in presentation and visualisation of uncertainty calculations, making the resulting graphical representations difficult to interpret 
and use (Clarke 2004). Planners, ultimately, will need to be able to assess the risk associated with using these datasets and models so that sound judgments can be made.

The second issue is the ability to represent easily the variability within geological units. Currently, the attributed 3D geological models presented here display the bulk attributes of a particular unit. The level of resolution is limited by the amount of data available on which to model a particular geological formation or member. Lack of data can therefore render some geological units nearly impossible to model, resulting in a significant loss of resolution to the model. Future work will have to focus on ways of representing property variation which is both realistic and understandable to land-use planners. These issues will need to be addressed if an uptake of digital geoscientific models and data is to be realised.

Finally, the key to the large-scale uptake of digital geoscientific data and 3D models within land-use planning is the efficient dissemination of this data, which will depend largely on the continued development of the Internet as a medium for the transfer of digital data and models. Already, Web-enabled platforms such as EISP are being developed, which will allow land-use planners to access geo-environmental information directly from the Internet. A future is imagined where a virtual site can be generated on a web based platform using a site's characteristics e.g. its geology, geography, past land-use and data on existing developments, which will enable developers to visualise the impact of their proposed projects from the comfort of their desk top PC.

\section{Acknowledgements}

This paper is published with the permission of the Executive Director of the British Geological Survey (NERC).

\section{References}

Anon. 1995. The Thames Gateway Planning Framework RPG9A. HMSO, 77.

Bates, M. R. 1998. Locating and evaluating archaeology below the alluvium: the role of subsurface stratigraphic modeling. Lithics 19, 4-18.

Bates, M. R. \& Bates, C. R. 2000. Multidisciplinary Approaches to the Geoarchaeological Evaluation of Deeply Stratified Sedimentary Sequences: Examples from Pleistocene and Holocene Deposits in Southern England, United Kingdom. Journal of Archaeological Science 27, 845-858.

Bell, F. G. \& Culshaw, M. G. 1998. Some geohazards caused by soil mineralogy, chemistry and mircrofabric: a review. In Maund J.G. and Eddleston M. (eds) Geohazards in engineering geology. Geological Society Engineering geology special publication 15, 427-441.

Berry, F. G. 1979. Late Quaternary scour hollows and related features in central London. Quarterly Journal of Engineering geology 12, 9-29.

Bobrowsky, P. T. 2002. Geoenvironmental mapping: methods, theory and practice. Lisse: AA Balkema.

Bowie, R. 2005. Creating a digital landslide. Geoscientist 15(3), 4-7.

Bristow, R., Mortimore, R. N. \& Wood, C. 1997. Lithostratigraphy for mapping the Chalk of southern England. Proceedings of the Geologist's Association 109, 293-315.

British Standards Institution. 1999. British Standard Code of Practice for Site Investigations. British Standards Institution, London, 150.

Brook, D. \& Marker, B. R. 1987. Thematic Geological Mapping as an essential tool in land use planning. In: Planning and Engineering geology (edited by Culshaw, M. G., Bell, 
F. G., Cripps, J. C. \& O’Hara, M.). Geological Society London Special Publication 4, 211-214.

Bruntland, G. 1987. Our Comman Future: World Commission on Environment and Development. Oxford University Press, Oxford.

Burnett, A. D. \& Fookes, P. G. 1974. A regional engineering geological study of the London Clay in the London and Hampshire Basins. Quarterly Journal of Engineering Geology 1, 257-296.

Canadian Institute of Planners. 2000. What do planners do? About Planning. Canadian Institute of Planners. Available from http://www.cipicu.ca/English/aboutplan/what.htm

Chandler, R. J. \& Apted, J. P. 1988. The effect of weathering on the strength of London Clay. Quarterly Journal of Engineering Geology 21, 59-68.

CIRIA. 2001. Sustainable urban drainage systems - best practice manual. Construction Industry Research and Information Association publication London: CIRIA.

Clarke, S. M. 2004. Confidence in geological interpretation. A methodology for evaluating uncertainty in common two and three-dimensional representations of subsurface geology. British Geological Survey Internal Report, IR/04/164.

Communities and Local Government. 2006. Planning Policy Statement 25: Development and Flood Risk. Full regulatory Impact Assessment. Communities and Local Government Publications.

Culshaw, M. G. 2003. Bridging the gap between geoscience providers and the user community. In: New paradigms in subsurface prediction (edited by Rosenbaum, M. S. \& Turner, A. K.) Lecture notes in earth sciences 99. Springer-Verlag, Berlin, 7-26.

Culshaw, M. G. 2005. From concept towards reality: developing the attributed 3D model of the shallow subsurface Quarterly Journal of Engineering geology and Hydrogeology 39, 231-284.

Culshaw, M. G. \& Ellison, R. A. 2002. Geological maps: their importance in a user-driven digital age. In: Proceedings of the 9th International Association for Engineering Geology and the Environment Congress, Durban, 16-20 September 2002 (edited by Van Roony, J. L. \& Jermy, C. A.) Keynote Lectures and Extended Abstracts Volume. Pretoria: South African Institute of Engineering and Environmental Geologists 25-51.

Culshaw, M. G., Forster, A. \& Northmore, K. J. 1994. Environmental geology maps for urban Britain - their relevance to less developed countries. . In: Proceedings of LANDPLAN IV (edited by Wang Sijing \& Wang Cunyu), Beijing 373-386.

Culshaw, M. G., Nathanial, C. P., Leeks, G. J. L., Alker, S., Bridge, D. M., Duffy, T., Fowler, D., Packman, J. C., Swetnam, R., Wadsworth, B. \& Wyatt, B. 2006. The role of webbased environmental information in urban planning - the environmental information system for planners. Science of the Total Environemt 360, 233 - 245.

De Mulder E.F.L. 1988. Thematic applied Quarternary maps - a profitable investment or expensive wallpaper? In: De Mulder E.F.L, Hageman B.P. (eds) Applied Quaternary Geology, Balkema, Rotterdam, pp 105-117

Department for communities and local Government. 2006. Planning Policy Statement 9: Biodiversity and geological conservation. Final Regulatory Impact Assessment. DCLG publications.

Dimmock, P. S. \& Mair, R. J. 2007. Volume loss experienced on open-face London Clay tunnels. Geotechnical Engineering 160(1), 3-11.

Dochartaigh, B. E., Ball, D. F., Macdonald, A. M., Lilly, A., Fitzsimons, V., Del Rio, M. \& Auton, C. A. 2005. Mapping groundwater vulnerability in Scotland: a new approach for the Water Framework Directive. Scottish Journal of Geology 41(1), 21 - 30. 
Doornkamp, J. C. 1995. Perception and Reality in the Provision of Insurance against Natural Perils in the UK. Transactions of the Institute of British Geographers 20(1), 68-80.

Ellison, R. A., Arrick, A., Strange, P. J. \& Hennessey, C. 1998. Earth science information in support of major development initiatives. British Geological Survey Technical Report. WA/97/84.

Ellison, R. A., McMillan, A. A. \& Lott, G. K. 2002. Ground characterization of the urban environment: a guide to best practice. In: British Geological Survey Internal Report. IR/02/044.

Ellison R.A., Woods M.A., Allen D.J., Forster A, Pharoah T.G., King C. 2004. Geology of London, British Geological Survey, Keyworth, pp 114

Forster, A. 1999. The Engineering geology of the London area: 1:50000 geological sheets 256, 257, 270 and 271. British Geological Survey, Engineering Geology Series, Technical Report WN/97/27.

Hack, R., Orlic, B., Ozmutlu, S. \& Rengers, N. 2006. Three and more dimensional modelling in geo-engineering. Bulletin of Engineering Geology and the Environment 65, 143153.

Hight, D. W. \& Jardine, R. J. 1993. Small strain stiffness and strength characteristics of hard London Tertiary clays. Geotechnical Engineering of Hard Soils-Soft Rocks 1(Athens), 533-552.

Hinze, C., Sobisch, H.-G. \& H-H, V. 1999. Spatial modelling in geology and its practical use. Mathematische Geologie 4, 51-60.

Howland, A. F. 2000. The history of the development of procedure for the rapid assessment of environmental conditions to aid the urban regeneration process at LondonDocklands. Engineering geology 60, 117-125.

Hutchinson, H. (1965). A survey of the coastal landslides of Essex and South Suffolk. Note Number EN/36/65. Building Research Station

Jackson, C.R. 2001. The development and validation of the object-oriented quasi three-dimensional regional groundwater model ZOOMQ3D. British Geological Survey Internal Report IR/01/144.

Jackson, I. 2004. Britain beneath our feet. In: British Geological Survey Occassional Publication No. 4, 114.

Kaalberg, F., Haasnoot, J. \& Netzel, H. 2003. what are the end-user issues? Settlement risk management in underground construction. In: New paradigms in subsurface prediction (edited by Rosenbaum, M. S. \& Turner, A. K.) Lecture notes in earth sciences 99. Springer-Verlag, Berlin, 69-84.

Kessler, H. \& Mathers, S. 2004. Maps to Models. Geoscientist 14(10), 4-6.

Lawrence, D. J. D., Arkley, S., Everest, J. D., Clarke, S. M., Millward, D., Hyslop, E. K., Thompson, G. L., Young, B. B. B., Survey, B. G. \& Britain), M. I. R. O. G. 2007. Northumberland National Park : Geodiversity Audit and Action Plan. British Geological Survey report, CR/07/037N.

Lelliott, M. R., Bridge, D. M., Kesslar, H., Price, S. J. \& Seymour, K. J. 2006. The application of 3D geological modelling to aquifer recharge assessments in an urban environment. Quarterly Journal of Engineering Geology and Hydrogeology 39, 293302.

Marker, B. R. 1998. Incorporation of information on geohazards into the planning process. In: Geohazards in engineering geology (edited by Maund, J. G. \& Eddleston, M.) 15. Geological Society Engineering geology special publication, 385-389.

McKirdy, A. P., Thompson, A. \& Poole, J. 1998. Dissemination of information on the earth sciences to planners and other decision-makers. . In: Issues in environmental geology: a British perspective. (edited by Bennett, M. R. \& Doyle, P.). Oxford: The Geological Society of London. 
McMillan, A. A., Heathcote, J. A., Klink, B. A., Shepley, M. G., Jackson, C. P. \& Degnan, P. J. 2000. Hydrogeological characterisation of the onshore Quaternary sediments at Sellafield using the concept of domains. Quarterly Journal of Engineering Geology and Hydrogeology 33, 301-323.

Nickless, E. F. P. 1982. Environmental geology of the Glenrothes district, fife region. Description of 1:25 000 sheet NO 20. In: Institute of Geological Sciences Report 82, 15.

Office of the Deputy Prime Minister. 2003. Sustainable communities: building for the future.

Office of the Deputy Prime Minister \& Department of Environment Food and Rural Affairs. 2004. Creating Sustainable Communities: Greening the Gateway. Office of the Deputy Prime Minister, London.

Office of the Deputy Prime Minister. 2004. Planning Policy Statement 23: Planning and Pollution control. Her Majesty's Stationery Office.

Paul, T., Chow, F. \& Kjekstad, O. 2002. Hidden Aspects of urban planning - surface and underground development. Thomas Telford Publishing, London.

Royse, K. R., Price, S., Entwisle, D., Lelliott, M. \& Terrington, R. 2005. Thames Gateway Pilot Study, Results: Is there a need for Urban Geoscience in the Gateway? British Geological Survey IR/05/063, 34.

Site investigation Steering Group. 1993. Without site investigation ground is a hazard. In: Site Investigation in construction Thomas Telford London, 56.

Smith, A. \& Ellison, R. A. 1999. Applied geological maps for planning and development: a review of examples from England and Wales, 1983 to 1996. Quaternary Journal of Engineering Geology 32, S1 - S44. .

Sobisch, H.-G. 2000. Ein difitles raeumliches Modell des Quartaers der GK25 Blatt 3508 Nordhorn auf der Basis vernetzer Profilschnitte. Shaker Verlag, Aachen.

Steadman, E. J., Mitchell, P., Highley, D. E., Harrison, D. J., Linley, K. A., Macfarlane, M. \& McEvoy, F. M. 2004. Strategic environmental assessment (sea) and future aggregate extraction : in the East Midlands region. British Geological Survey report CR/04/003N.

Strange, P. J., Booth, S. J. \& Ellison, R. A. 1998. Development of 'rockhead' computergenerated geological models to assist geohazard prediction in London. In: Geohazards in engineering geology (edited by Maund, J. G. \& Eddleston, M.) 15. Geological Society Engineering Geology Special Publication, 409-414.

The Mayor of London. 2004. The London Plan: Spatial development strategy for Greater London. Greater London Authority.

Thompson, A., Hine, P. D., Grief, J. R. \& Poole, J. S. 1998. Environmental geology in Land Use and Planning: Advice for Planners and developers. Report to the Department of the Environment.

Turner, A. K. 2003. Putting the user first: implications for subsurface characterisation. In: New paradigms in subsurface prediction (edited by Rosenbaum, M. S. \& Turner, A. K.) Lecture notes in earth sciences 99. Springer - Verlag, Berlin, 61-83.

Turner, A. K. 2006. Challenges and trends for geological modelling and visualisation. Bulletin of Engineering Geology and the Environment 65, 109 - 127. 


\section{FIGURE CAPTIONS}

Fig. 1. Geological map of London and the Thames Gateway area.

Fig. 2. Flow diagram showing the process of building and attributing the 3D geological model

Fig. 3. Diagram of the 3D geological model building work flow (after Kessler \& Mathers 2005).

Fig. 4. 3D geological model of the Thames Gateway Development Zone from Stratford in the west to Canvey Island in the east. Areas of peat (brown) are revealed beneath deposits of alluvium (yellow), river terrace deposits (orange) and anthropogenic deposits (grey). Bedrock is composed of Palaeogene deposits (orange, blue and pink) underlain by Chalk (green).

Fig. 5. Contour map of the thickness of the alluvium between Bexley and Tilbury displayed in ArcGIS generated from the 3D geological model.

Fig. 6. 3D property and geological models for West Thurrock; a) is the geological model (see Fig. 1 for details of the stratigraphy) and b) is a property model displaying the differences in permeability between the geological units, high permeability in red, low permeability in green and variable permeability in orange.

Fig. 7. Diagram indicating how a 3D geological model can be used to generate thematic 2D maps by incorporating other geo-environmental datasets and using spatial queries available within standard GIS packages.

Fig. 8. 3D geological model of a railway route from Purfleet to East Tilbury, London with automatically generated geological and engineering geological cross-sections.

Fig. 9. Excerpt from BGS GeoSureV3.1 dataset showing the shrink-swell potential in the Hadleigh area

Fig. 10. Excerpt from BGS GeoSureV3.1 dataset showing the slope-instability potential in the Hadleigh area. 
TABLES

\begin{tabular}{|c|c|}
\hline Planners and Developers Needs & Data outputs from the attributed geological model \\
\hline $\begin{array}{l}\text { To make the best use of natural } \\
\text { resources and protect and conserve } \\
\text { their regions natural heritage }\end{array}$ & $\begin{array}{l}\text { - Location, thickness and distribution of mineral } \\
\text { rich geological units } \\
\text { - } \quad \text { hydrogeological domain and aquifer } \\
\text { vulnerability maps } \\
\text { - } \quad \text { Improved ground water models } \\
\text { - } \quad \text { Identification of geological strata rich in } \\
\text { - } \text { archaeological finds } \\
\text { - } \quad \text { Peo-diversity maps } \\
\text { maps at the level of build }\end{array}$ \\
\hline $\begin{array}{l}\text { To ensure that development takes } \\
\text { place in the right place and is } \\
\text { properly designed }\end{array}$ & $\begin{array}{l}\text { - } \text { Geological maps and models } \\
\text { - } \text { Foundation condition maps SUDS initial } \\
\text { - } \text { Geohazard maps } \\
\text { - } \text { Site Investigation planning tools/ models } \\
\text { - } \text { depth of build } \\
\text { - Underground asset management systems } \\
\text { - Decision support tools }\end{array}$ \\
\hline $\begin{array}{l}\text { Be able to set broad polices for land } \\
\text { use in a particular area }\end{array}$ & $\begin{array}{l}\text { - } \text { Regional attributed geological models } \\
\text { - } \text { Geohazards maps and models } \\
\text { - } \text { Environmental Information systems } \\
\text { - } \\
\text { Decional groundwater management plans } \\
\text { Dupport tools }\end{array}$ \\
\hline
\end{tabular}

Table 1. Lists the needs of developers and planners and the types of uses to which the 3D attributed digital geological model could be used in planning and development to answer these needs. 


\begin{tabular}{|c|c|c|c|c|}
\hline \multicolumn{2}{|c|}{ ENGINEERING UNIT } & GEOLOGICAL UNIT & CHARACTERISTICS & ENGINEERING CONSIDERATION \\
\hline \multicolumn{5}{|c|}{ SOIL } \\
\hline Organic & 1 & Peat & $\begin{array}{l}\text { Very soft to firm, fibrous or amorphous dark } \\
\text { brown, or black clayey PEAT occasionally woody } \\
\text { or with layers of shells. }\end{array}$ & $\begin{array}{l}\text { Highly compressible, even light foundation will be subject to variable and } \\
\text { considerable settlement over long periods. Dewatering produces } \\
\text { considerable and prolonged settlement. May produce acidic groundwater. }\end{array}$ \\
\hline \multirow[t]{3}{*}{$\begin{array}{l}\text { Mixed } \\
\text { Soils }\end{array}$} & 2 & $\begin{array}{l}\text { Worked and Made } \\
\text { Ground }\end{array}$ & $\begin{array}{l}\text { Highly variable, very soft to stiff, uncompact to } \\
\text { compact, loose to dense, CLAY, SILT, SAND, } \\
\text { GRAVEL and COBBLE, may include man made } \\
\text { materials. May be compacted. }\end{array}$ & $\begin{array}{l}\text { Highly variable ground conditions, depending on content and whether it is } \\
\text { engineered. May be contaminated. May produce explosive or noxious } \\
\text { gasses. }\end{array}$ \\
\hline & 3 & Engineered Embankments & $\begin{array}{l}\text { Highly variable generally stiff or dense compacted } \\
\text { CLAY, SILT, SAND, GRAVEL, may include } \\
\text { manmade materials. Compacted }\end{array}$ & Mostly suitable for foundations depending on construction methods. \\
\hline & 4 & $\begin{array}{l}\text { Lambeth Group and } \\
\text { Harwich Formation }\end{array}$ & $\begin{array}{l}\text { Highly variable lithologies, firm to hard CLAY } \\
\text { occasional weak CLAYSTONE, compact SILT, } \\
\text { dense to very dense SAND and/or flint GRAVEL, } \\
\text { some shelly or SHELL beds, occasional weak } \\
\text { limestone, occasionally organic. Lithological } \\
\text { variation often unpredictable. }\end{array}$ & $\begin{array}{l}\text { Generally good foundation material, however, the lithological variability } \\
\text { gives rise to variable groundwater conditions including lenticular water } \\
\text { bearing sands. Variability provides difficult to very difficult tunnelling } \\
\text { and deep excavations conditions. Fissuring in clays may affect the } \\
\text { stability of cuttings. }\end{array}$ \\
\hline \multirow[t]{3}{*}{ Fine } & 5 & Alluvium & $\begin{array}{l}\text { Very soft to soft sometimes firm, sometimes } \\
\text { laminated, often organic, sometimes with shelly } \\
\text { CLAY. Top } 2 \text { to } 3 \text { metres may be firm to stiff due } \\
\text { to desiccation. }\end{array}$ & $\begin{array}{l}\text { Generally highly compressible, bearing capacities less than } 100 \mathrm{kPa} \text {. } \\
\text { Light foundation may be subject to variable and considerable settlement } \\
\text { over long periods. Dewatering produces considerable and prolonged } \\
\text { settlement. }\end{array}$ \\
\hline & 6 & $\begin{array}{l}\text { Crayford Silt and Ilford } \\
\text { Silt Formations }\end{array}$ & $\begin{array}{l}\text { Uncompact to compact often with vertical fissure, } \\
\text { SILT or firm CLAY }\end{array}$ & $\begin{array}{l}\text { Some parts have high porosity and open structure which may be prone to } \\
\text { collapse on loading and wetted. Generally well drained, used in the } \\
\text { manufacture of bricks (hence 'brickearth'), excellent agricultural land. }\end{array}$ \\
\hline & 7 & London Clay Formation & $\begin{array}{l}\text { Firm to stiff becoming very stiff or hard at depth, } \\
\text { near surface generally fissured, brown often with } \\
\text { gypsum otherwise grey, CLAY sometimes compact } \\
\text { SILT, occasionally dense to very dense SAND. }\end{array}$ & $\begin{array}{l}\text { Near surface prone to shrink/swell affecting shallow foundations, planting } \\
\text { or removal of trees near buildings may exacerbate this. Depth of } \\
\text { weathering, and fissuring varies. }\end{array}$ \\
\hline \multirow[t]{2}{*}{ Coarse } & 8 & $\begin{array}{l}\text { Shepperton, Kempton } \\
\text { Park, Taplow, Hackney } \\
\text { and Lynch Hill Gravels } \\
\text { Formations }\end{array}$ & $\begin{array}{l}\text { Generally moderately dense to dense, sometimes } \\
\text { very dense SAND or Gravel or mixture of the two, } \\
\text { sometimes silty or clayey with local lenses of silt, } \\
\text { clay or peat. }\end{array}$ & $\begin{array}{l}\text { Generally good foundation condition. Excavations may require } \\
\text { dewatering and are generally unstable. High water table in excavations } \\
\text { may lead to running sand conditions. }\end{array}$ \\
\hline & 9 & Thanet Sand Formation & $\begin{array}{l}\text { Very dense, slightly silty or clayey to silty to } \\
\text { clayey fine SAND, with gravel to cobble flint at } \\
\text { base (Bullhead Beds). }\end{array}$ & $\begin{array}{l}\text { Generally high bearing capacity but may be lower near surface where } \\
\text { weathered/cryoturbated. Requires dewatering in tunnelling and deeper } \\
\text { excavation. Water pressures often artesian where this formation is below } \\
\text { clay. }\end{array}$ \\
\hline \multicolumn{5}{|r|}{ ( } \\
\hline Chalk & 10 & $\begin{array}{l}\text { Seaford and Newhaven } \\
\text { Formations }\end{array}$ & $\begin{array}{l}\text { Comminuted to high density CHALK, } \\
\text { variable weathering depth, sometimes karstic. }\end{array}$ & $\begin{array}{l}\text { Depends on degree and depth of weathering and the presence of karst } \\
\text { Bearing capacity generally good where not highly weathered, however, } \\
\text { both bored and driven piles have little friction. }\end{array}$ \\
\hline
\end{tabular}

Table 2. Engineering classification of the geological units encountered in the central part of the Thames Gateway area (after Entwisle per com.). 
